\title{
IMPACT OF REGIONAL DISTRIBUTION AND AIR POLLUTION ON INTERNAL STRUCTURE OF MELIA AZEDARACH L. LEAVES
}
V. Abozaid ${ }^{1}$
H. Arif Abdulrahman ${ }^{1}$
D. Ayoub Ibrahim ${ }^{2}$

Assist. lecturer

Lecturer

Prof.

${ }^{1}$ Dept. Biol. ,Fac.Sci. University Zakho. ${ }^{2}$ Scien. Res. Cent,Coll. Sci, University Duhok. Vameen.taher@uoz.edu.krd haliz.abdulrahman@uoz.edu.krd diaa.ibrahim@uod.ac ABSTRACT

This study was performed to investigate the impact of air pollution on leaf area and anatomical features of Melia azedarach $\mathrm{L}$. trees, in urban areas with three demographical classes :location (I) industrial area, location (II) roadside area and free parts (control area) as a location (III) of Duhok city/Kurdistan Region-Iraq, during July 2021. The results demonstrated that the leaf area of selected plants' leaves in location I had reduced with no noticeable change in the average stomata density in the three locations I, II and III. Meanwhile, the results of the most anatomical features of the blade (blade, lower cuticle, epidermis (both upper and lower) thickness, palisade layer height and spongy parenchyma width) in addition to midrib parameters (epidermis thickness (upper and lower), collenchyma and parenchyma layer width, phloem and xylem width and pith diameter) were decreased in both locations I, II, and with well-developed anatomical features in location III.

Keywords: Melia azedarach L., air pollution, leaf blade, midrib, stomata density, leaf area.

Melia azedarach L. تأثير التوزيع المناطقي و تلوث الهواء في التركيب الداخلي لأولق السبحبح

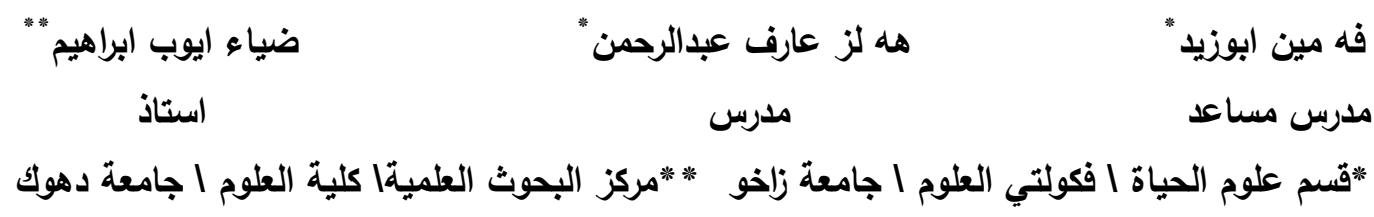

المستخلص

Melia azedarach اجريت هذه الدراسة بهدف دراسة تأثير تلوث الهواء على مساحة الأورلق والسمات التشريحية لأثجار

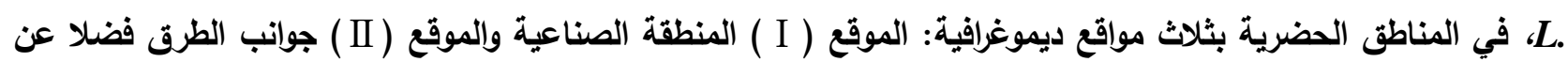
المناطق المفتوحة والمتمثلة بالموقع (III) لمدينة دهوك / إقليم كردستان العراق، خلال شهر تموز 2021. على أن مساحة الأولق في الموقع الاول قد تقلصت مع عدم وجود تغيير ملحوظ في متوسط كثافة الثخور في المناطق الثثلاثة

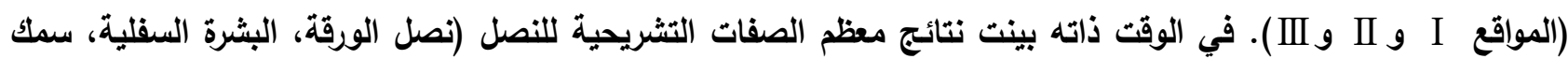
البشرة (العلوية والسفلية)، ارتفاع طبقة العمادية وعرض الطبقة الإسفنجية) فضلا عن الصفات التشريحية للعرق الوسطي

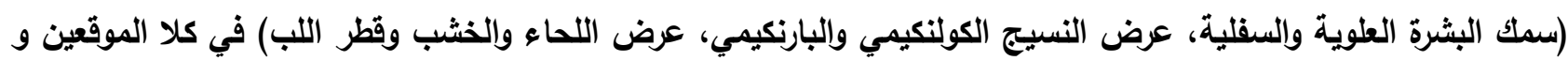

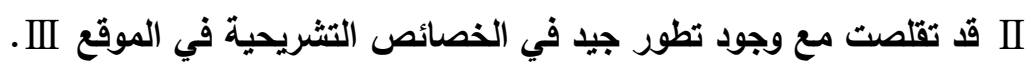

الكلمات المفتاحية: .Melia azedarach L. تلوث الهواء ، نصل الورقة ، العرق الوسطي ، كثافة الثغور ، مساحة الورقة. 


\section{INTRODUCTION}

Chinaberry tree (Melia azedarach L.) belongs to Meliaceae family which includes 50 genera with 1400 species, it considered as deciduous trees with high reach up to $12 \mathrm{~m}$ and pinnate leaves, opposite arrangement leaflets and drupe fruit (24). Mature leaves gain a stink smells and poisonous effects. The fruit color progress from green at juvenal age to light yellow and brown at repining stage (8). The native habitat of this tree is tropical region originated in Asia, spread and transplants in a various tropics and subtropical countries, such as United States of America, Argentine, Brazil, Philippines and Africa, it has been broadly cultivated in various area of Kurdistan region (3). This species adapts well to poor soils, warm temperatures, and seasonally dry conditions. It is widely dispersed, dries quickly, and is easy to process without cracking or warping (2). Although the fruits might be poisonous for the humans and definite mammals, it may use in many countries as a traditional medicinal product for anti-parasitic and anti-fungal properties. Nevertheless, overdose could lead to death (20). Trees are mainly used by roadsides and in urban green areas due to their different functions the yellow color of leaves in autumn, aromatic flowers and in winter its aesthetical fruits (19). The plant also has the ability to improve the environmental quality by accumulating several pollutants in their leaves, roots, trunks, barks or fruits, these accumulations are used as appropriate in order to monitor the traffic-related air pollution (17), to reduce the effect of the presences of high concentration of heavy metals through agrochemical fertilizer, insecticides and waste products and gases of factories that considered as the main source of pollution of soil and atmosphere (25). Pollutants from a various source, including industrial processes, paved and unpaved roads, building and demolition sites, cause substantial internal and exterior harm to plants and it's cells, these contaminants mostly affect plants, particularly trees growing along roadsides, through their leaves "rather than the stem or roots" is the most sensitive component of the body to air pollution (14). Mitu et al (16) showed that the epidermis, palisade, and spongy parenchyma had reduced cell size of plants in polluted areas, with a black dot-like substance deposited in those parts, on the other hand, the leaves of control site plants, had normal anatomy. Moreover, Kushwaha et al (15) found that the anatomical properties of Nerium oleander leaves had changed significantly in contaminated region samples on both the upper and lower surface of the leaf, by increasing in the number of stomata and epidermal cells, along with a decrease in the length and width of guard and epidermal cells. This study was investigated to examine the leaf area and anatomical features of Melia azedarach $\mathrm{L}$. trees as a result to air pollution in addition to their demographical distribution in different areas of Duhok province.

\section{MATERIAIS AND METHODS}

Samples of Melia azedarach L. leaves have been taken from trees growing at urban areas of Duhok city Kurdistan Region-Iraq. The urban area was divided into three demographical classes: location (I) industrial area, location (II) roadside area and free parts of the Duhok with thin population and with no industrial activities (control area) as a location (III) at the same age nearly 8 years. At each area, 25 samples of leaves were collected from each site during July 2021. The samples were kept in plastic bags then, transported to the laboratory for morphological and anatomical investigations. The samples were prepared in order to determine the leaf area $\left(\mathrm{cm}^{2}\right)$ according to Abdel (1). Stomata density which include the number of stomata in one $\mathrm{mm}^{2}$ has been calculated. For anatomical study and slide preparation, the samples were fixed in Formalin, Glacial Acetic Acid, Alcohol (70\%) FAA (5:5:90) $\mathrm{ml}$, respectively (4). The cross sections of samples were stained with safranin and fast green (9), then they were mounted in Canada balsam for 24 hours. The observed cross sections parameters include stomata density, thickness of blade, cuticle (upper and lower), epidermis (upper and lower) and in mesophyll layers (palisade layer height and spongy parenchyma width). For leaf midrib, the thickness of upper and lower cuticle, the upper and lower epidermis, collenchyma and parenchyma layer width, phloem and xylem width in addition to pith diameter were examined under light microscope (Motic) for 
description of anatomical features and estimating the measurements of its components. For suitable images were photographed by using Dino-eye digital camera.

\section{RESULTS AND DISCUSSION}

Leaf area and stomata density: The average leaf area and the range in Table (1) shows a reduction in the leaf area of Melia azedarach L. which was collected from locations I and II (5 and $\left.4.40 \mathrm{~cm}^{2}\right)(2.14-9.36$ and 2.43-6.98 $\mathrm{cm}^{2}$ ) respectively, while the highest average of leaf area was $\left(10.14 \mathrm{~cm}^{2}\right)$ recorded in location
III. These differences in leaf size and color can easily be observed in Figure (1). The biggest leaf area with dark green appeared very clear in the control leaf samples collected from location III. On the other hand, there was no difference in average of stomata density among the three locations and it was quite clear that the highest average stomata density was $\left(113.13 \mathrm{~mm}^{2}\right)$ and the range reached $(90-$ $140 \mathrm{~mm}^{2}$ ) found in location I, as shown in Table (1).

Table 1. The measurements of leaf area and stomata density of Melia azedarach $\mathrm{L}$. from three different locations*

\begin{tabular}{|lcccc|}
\hline \multirow{2}{*}{ Characters } & Statistics & \multicolumn{3}{c|}{ Melia azedarach $\mathrm{L}}$. \\
& & I & II & III \\
\hline \multirow{2}{*}{ Leaf area $\left(\mathrm{Cm}^{2}\right)$} & Average & 5 & 4.40 & 10.14 \\
& Range & $2.14-9.36$ & $2.43-6.98$ & $6.98-16.5$ \\
Stomata density $\left(\mathrm{mm}^{2}\right)$ & Average & 113.13 & 108.5 & 104.6 \\
& Range & $90-140$ & $80-145$ & $82-136$ \\
\hline
\end{tabular}

*The value in the table represent the average of 25 observations for each quantitative character. ( $\mathrm{I}=$ Industrial area, $\mathrm{II}=$ Roadside area and $\mathrm{III}=$ control area).

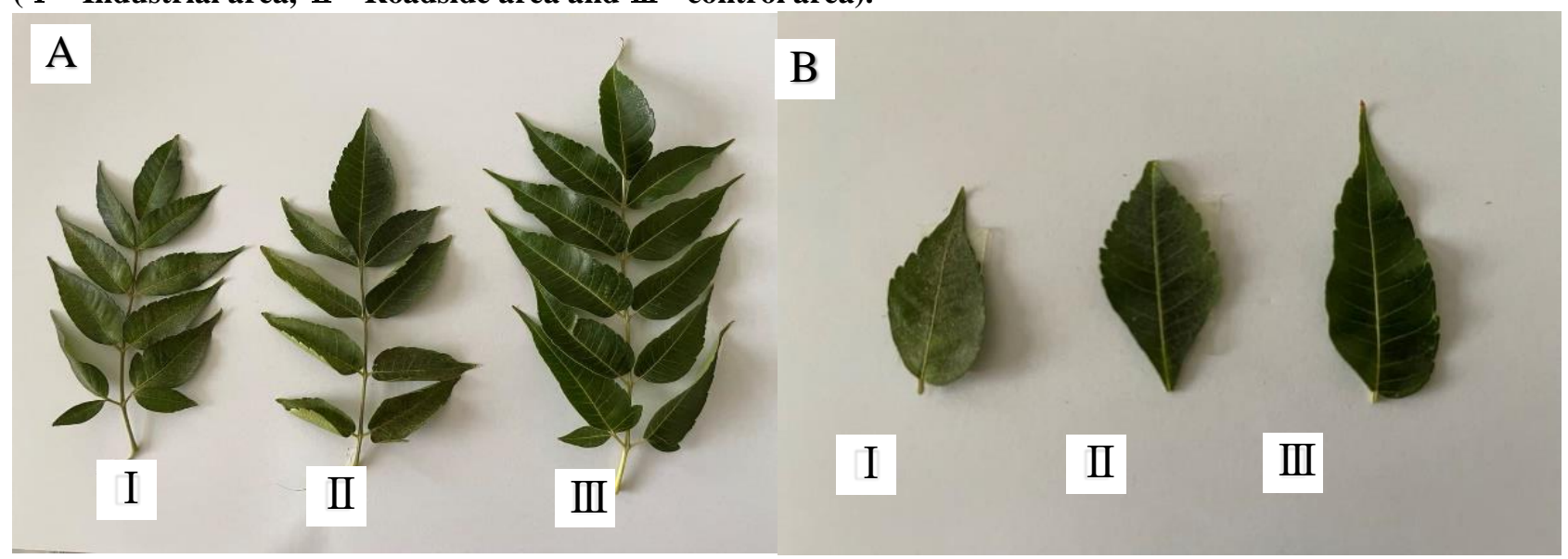

Figure 1. Leaf of Melia azedarach L. grown industrial area ( I ), roadside area ( II) and control area (III). A: compound leaf, B: leaflet

Leaf blade: The average of blade thickness of Melia azedarach L. in Table (2) show the thickest blade in location III $(165.6 \mu \mathrm{m})$ and the thinnest in location I $(140.1 \mu \mathrm{m})$ with the range $(117.6-251.1 \mu \mathrm{m})$. In contrast, the highest average $(4.1 \mu \mathrm{m})$ of upper cuticle thickness appears in location I. However, there was no difference between the locations (I, II and III) in lower cuticle thickness. While the highest average of upper and lower epidermis was recorded (13.4 and $10 \mu \mathrm{m})$ respectively in location III, and the lowest one was $(9.4$ and $5.4 \mu \mathrm{m})$ respectively in location I. At the same time, the highest average of palisade layer height and spongy parenchyma width was seen in location III and the lowest was in location I $(74.8,60.6,57.9$ and 49.4 $\mu \mathrm{m})$ respectively. 
Table 2. The measurements of blade components of Melia azedarach $\mathbf{L}$. at three different locations*

\begin{tabular}{|c|c|c|c|c|}
\hline \multirow{2}{*}{ Characters } & \multirow{2}{*}{ Statistics } & \multicolumn{3}{|c|}{ Melia azedarach $\mathbf{L}$. } \\
\hline & & I & II & III \\
\hline Blade thickness $(\mu \mathrm{m})$ & $\begin{array}{c}\text { Average } \\
\text { Range }\end{array}$ & $\begin{array}{c}140.1 \\
117.6-152.7\end{array}$ & $\begin{array}{c}144.5 \\
129.5-167.2\end{array}$ & $\begin{array}{c}165.6 \\
118.3-251.1\end{array}$ \\
\hline Upper cuticle thickness & Average & 4.1 & 3 & 2.9 \\
\hline $\begin{array}{l}(\mu \mathrm{m}) \\
\text { Lower cuticle thickness }\end{array}$ & $\begin{array}{c}\text { Range } \\
\text { Average }\end{array}$ & $\begin{array}{l}2.2-4.7 \\
2.5\end{array}$ & $\begin{array}{c}1.6-4.7 \\
2.7\end{array}$ & $\begin{array}{l}1.2-4.6 \\
2.8\end{array}$ \\
\hline$(\mu \mathrm{m})$ & Range & $1-3.5$ & $1.6-4.3$ & $1.9-3.5$ \\
\hline $\begin{array}{l}\text { Upper epidermis thickness } \\
(\mu \mathrm{m})\end{array}$ & $\begin{array}{l}\text { Average } \\
\text { Range }\end{array}$ & $\begin{array}{c}9.4 \\
6.5-13.2\end{array}$ & $\begin{array}{c}11.5 \\
8.9-15.1\end{array}$ & $\begin{array}{c}13.4 \\
9.8-17.8\end{array}$ \\
\hline $\begin{array}{l}\text { Lower epidermis thickness } \\
(\mu \mathrm{m})\end{array}$ & $\begin{array}{c}\text { Average } \\
\text { Range }\end{array}$ & $\begin{array}{c}5.4 \\
3.6-7.2\end{array}$ & $\begin{array}{c}6.5 \\
5.4-9.7\end{array}$ & $\begin{array}{c}10 \\
7.4-13.8\end{array}$ \\
\hline Palisade layer height $(\mu \mathrm{m})$ & $\begin{array}{l}\text { Average } \\
\text { Range }\end{array}$ & $\begin{array}{c}57.9 \\
50.5-69.9\end{array}$ & $\begin{array}{c}63.6 \\
47.8-95.2\end{array}$ & $\begin{array}{c}74.8 \\
60.1-85.6\end{array}$ \\
\hline $\begin{array}{l}\text { Spongy parenchyma width } \\
(\mu \mathrm{m})\end{array}$ & $\begin{array}{c}\text { Average } \\
\text { Range }\end{array}$ & $\begin{array}{c}49.4 \\
32.4-65.6\end{array}$ & $\begin{array}{c}52.9 \\
42.4-66.2\end{array}$ & $\begin{array}{c}60.6 \\
40.9-78.3\end{array}$ \\
\hline
\end{tabular}

*The value in the table represent the average of 25 observations for each quantitative character. ( $\mathrm{I}=$ Industrial area, II = Roadside area and III= control area).

The blade transverse section of Melia azedarach L. in figure (2) shows that the adaxial (upper) surface is glossy covered with a thick waxy layer of cuticle in location I as compared with locations II and III. Beneath the upper cuticle, a single compact raw of almost rectangular shape of upper epidermis layer. The mesophyll layer is differentiated into palisade and spongy parenchyma layers, inner to the upper epidermis. The palisade

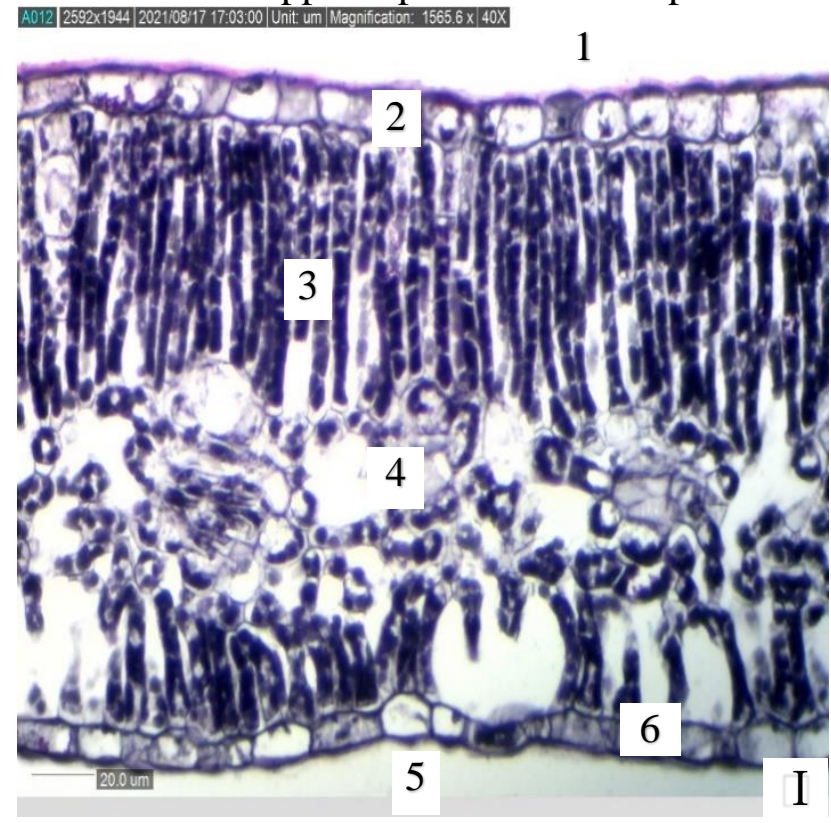

layers consist of one longitudinal cell layer free of intercellular space and rich of chloroplasts, while loose spongy parenchyma is formed by several irregular shape cell layers. Lower epidermis consists of a single rectangular layer of compact cell smaller than the upper epidermis. Abaxial (lower) surface covered with almost thin waxy cuticle layer, Stomata are Anomocytic type and hypostomatic condition

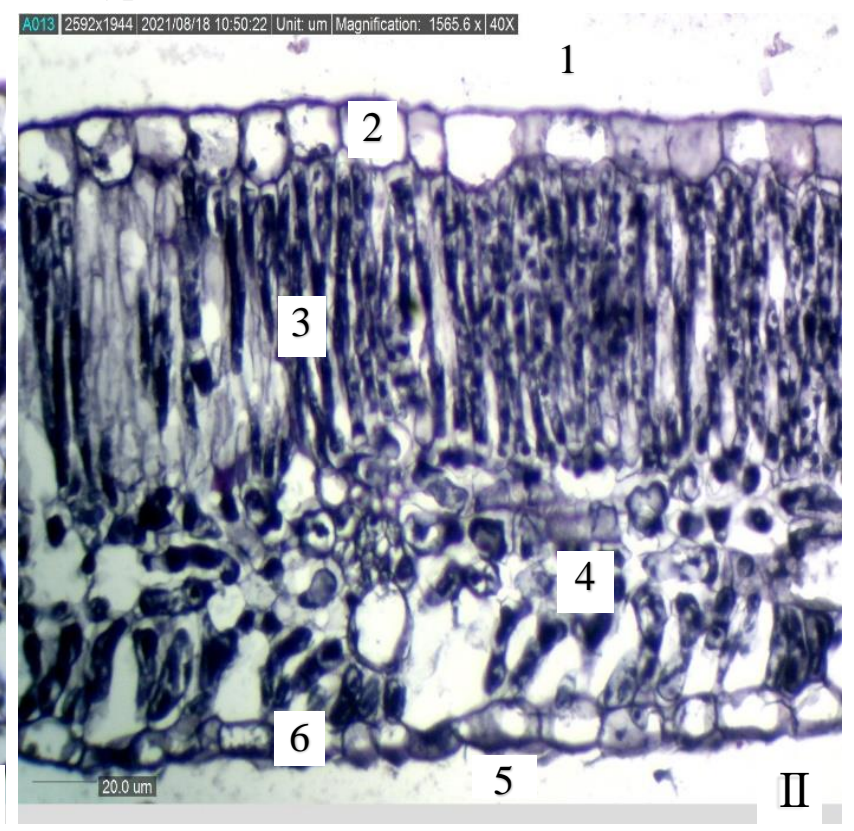




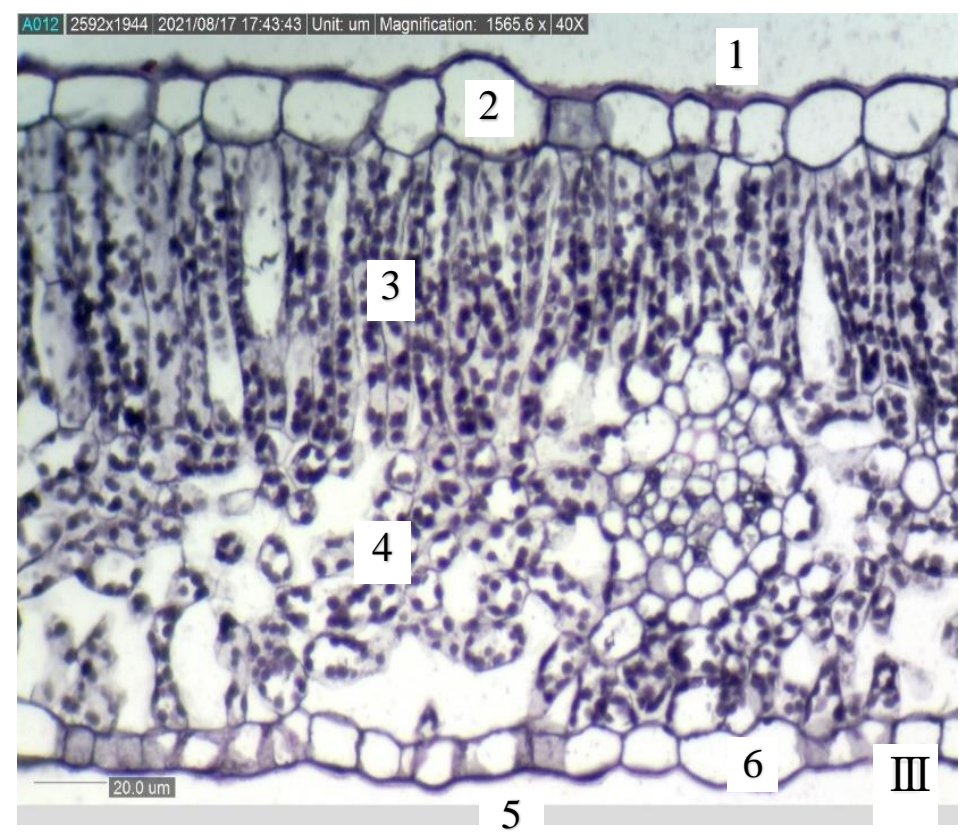

Figure 2. Blade transverse section of Melia azedarach $\mathrm{L}$. grown industrial area ( I ), roadside area (II) and control area (III). 1. Adaxial surface (upper), 2. Upper epidermis, 3. Palisade layer, 4. Spongy layer, 5. Abaxial surface (lower), 6. Lower epidermis

Midrib: The anatomical features of the midrib in table (3) illustrate that the average of upper cuticle thickness was high in location I . $(4.5 \mu \mathrm{m})$. However, the lowest average of upper cuticle thickness was seen in location II $(3.3 \mu \mathrm{m})$ while the average of lower cuticle thickness was nearly the same in three locations. On the other hand, the average of each of the following features: upper and

Table 3. The measurements of midrib components of Melia azedarach $\mathrm{L}$. at three different locations*

\begin{tabular}{|c|c|c|c|c|}
\hline \multirow{2}{*}{ Characters } & \multirow{2}{*}{ Statistics } & \multicolumn{3}{|c|}{ Melia azedarach $\mathbf{L}$. } \\
\hline & & I & II & III \\
\hline \multirow{2}{*}{$\begin{array}{l}\text { Upper cuticle thickness } \\
(\mu \mathrm{m})\end{array}$} & Average & 4.5 & 3.3 & 3.9 \\
\hline & Range & $2.8-5.9$ & $2.3-4.7$ & $3-4.9$ \\
\hline \multirow{2}{*}{$\begin{array}{l}\text { Lower cuticle thickness } \\
(\mu \mathrm{m})\end{array}$} & Average & 3 & 2.8 & 3.1 \\
\hline & Range & $2.1-4.2$ & $1.6-4.6$ & $2.1-4.9$ \\
\hline \multirow{4}{*}{$\begin{array}{l}\text { Upper epidermis thickness } \\
(\mu \mathrm{m}) \\
\text { Lower epidermis thickness } \\
(\mu \mathrm{m})\end{array}$} & Average & 9.9 & 9.3 & 11.4 \\
\hline & Range & $7.2-14.6$ & $7.2-11.5$ & $8.7-15.3$ \\
\hline & Average & 6.4 & 6.6 & 7.5 \\
\hline & Range & $3.7-8.8$ & $4.7-9.5$ & $4.3-9.7$ \\
\hline \multirow{4}{*}{$\begin{array}{l}\text { Collenchyma layer width } \\
(\mu \mathrm{m}) \\
\text { Parenchyma layer width } \\
(\mu \mathrm{m})\end{array}$} & Average & 20.5 & 21.3 & 25.9 \\
\hline & Range & $12-28.9$ & $12.8-42.8$ & $15.9-37.1$ \\
\hline & Average & 71.8 & 64.8 & 96.9 \\
\hline & Range & $56.2-138.4$ & $43-117.7$ & $69.7-154.4$ \\
\hline \multirow{2}{*}{ Phloem width $(\mu \mathrm{m})$} & Average & 45.6 & 45.7 & 60.3 \\
\hline & Range & $34.8-63.6$ & $27.1-74.4$ & $37.1-80.6$ \\
\hline \multirow{2}{*}{ Xylem width $(\mu \mathrm{m})$} & Average & 65.9 & 56.1 & 88 \\
\hline & Range & $44.8-80.9$ & $36.4-75.2$ & $58.9-112$ \\
\hline \multirow{2}{*}{ Pith diameter $(\mu \mathrm{m})$} & Average & 42.8 & 46.5 & 65.5 \\
\hline & Range & $32.9-59.1$ & $36.1-63$ & $53.6-74.6$ \\
\hline
\end{tabular}

*The value in the table represent the average of 25 observations for each quantitative character. ( $\mathrm{I}=$ Industrial area, $\mathrm{II}=$ Roadside area and $\mathrm{III}=$ control area). lower epidermis thickness, collenchyma and parenchyma layer width, phloem and xylem width and pith diameter in location III was the highest $(11.4,7.5,25.9,96.9,60.3,88$ and $65.5 \mu \mathrm{m})$ respectively, but the lowest average of them was fluctuating between location I and location II. 
The cross sections of Melia azedarach L. (Figure 3) reveals that the outline of midrib is nearly elliptic in shape. The adaxial (upper) surface is approximately in the form of a hump, while the abaxial (lower) is a semicircle. Both the cuticle and the epidermal layers of the adaxial surfaces are thicker than the abaxial surfaces. The adaxial surface of the midrib is made up of a single compact epidermis layer that is virtually rectangular in

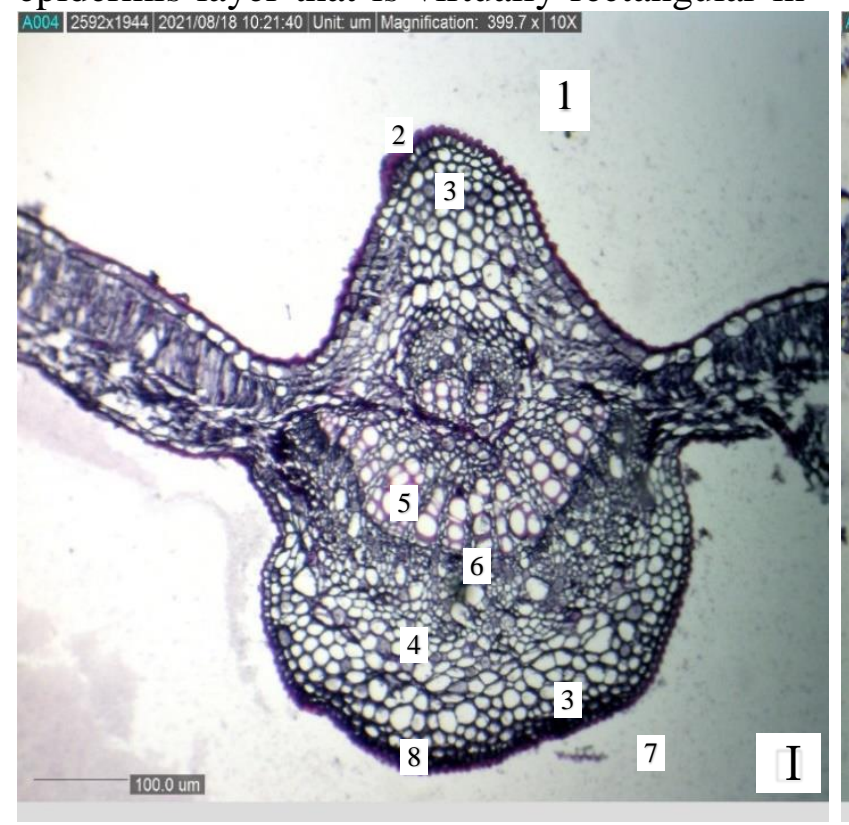

shape, while the abaxial surface is made up of a single epidermis row that is smaller than the upper epidermis. Underneath both epidermis layers are collenchyma layers. The collenchyma and the vascular bundle are separated by parenchyma layers. The central large vascular bundle consists of xylem elements toward the adaxial and phloem elements toward the abaxial. The stomata are present only on the lower surface.

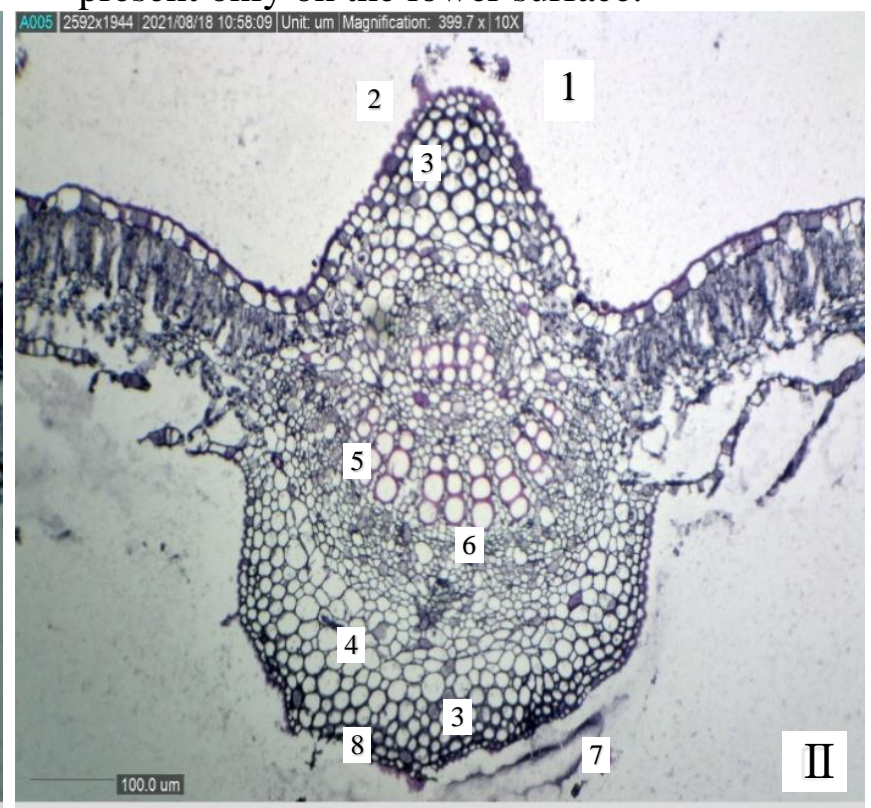

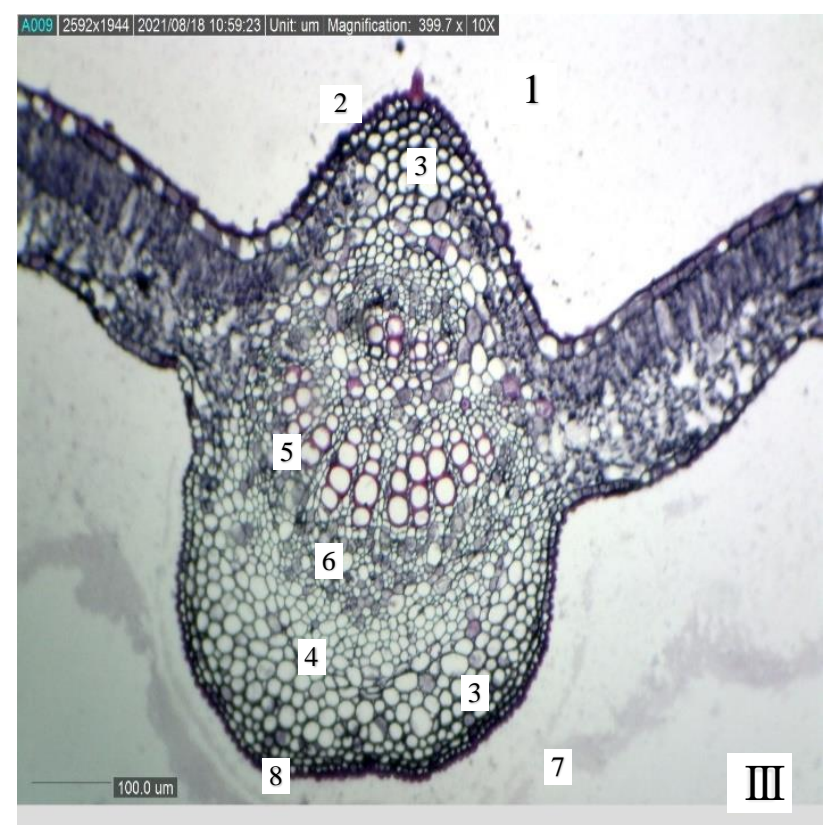

Figure 3. Midrib transverse section of Melia azedarach L. grown in industrial area ( I ), roadside area ( II ) and control area (III). 1. Adaxial surface (upper), 2. Upper epidermis, 3. Collenchyma layer, 4. Parenchyma layer, 5. Xylem, 6. Phloem, 7. Abaxial surface (lower), 8. Lower epidermis

rban and industries area constantly charge the environment with toxic compounds, thousands of organic trace contaminants have been generated and partially discharged into the environment over the previous few decades (18). Numerous industrial activities damage 
various environmental components such as water, air, soil, and plant growth (5). Plants growing in polluted environmental conditions, such as industrial area or by the highway, have morphologically and anatomically different leaves, stems, and roots as a result of air and soil pollution than plants growing in more favorable conditions (12). Results of leaf area and anatomical features of Melia azedarach L. leaves showed that the leaf area and the most of anatomical features of leaf blade and midrib growing at different polluted locations ( $\mathrm{I}=$ industrial area, $I I=$ roadside area) were reduced when compared to the location (III) control area. Plants respond to industrial and vehicular air pollution stress through a number of active morphological and anatomical responses, including changes in stomata and epidermal cell size and stomata frequency, as well as the stomatal index (28). This reduction in stomata density and size could be viewed as a plant's adaptive response to avoid toxic ingredients from industrial and vehicle exhaust from entering the plant, which could otherwise have negative consequences (23). Moreover, El-Khatib et al (11) found that the stomata were denser and smaller in size than those in the control group also, the cuticle, epidermis, palisade tissue, mesophyll tissue, and parts of the vascular cylinder (xylem and phloem) of olive leaves reflected the deterioration impacts of cement dust air pollution. A similar reduction in leaf area and epidermal cells is found at polluted urban sites compared to the reference site (26 and15). Rai (21) showed that air pollution induced significant alterations in foliar morphology as well as biochemical parameter abnormalities. In addition, similar results have been recorded by each of $(27,7$, 13 and 10). Due to the stress of automotive exhaust emissions with high traffic density in metropolitan areas, the morphological traits of plants and the leaf surface properties, including stomata and epidermal cells, of plant species growing along road sides are significantly affected (6 and 22).

\section{CONCLUSION}

Plants generally respond to air pollution in the similar way they respond to drought and other environmental stresses. It is concluded that the low-polluted areas reduce the changes in the phenotypic and anatomical characteristics of the plant, unlike the more polluted areas, which affect the anatomical structure and thus the plant physiology.

\section{REFERENCES}

1. Abdel, C.G. 1994. Rapid methods for estimating leaf area and size in field bean (Vicia faba L). Tech. Res. 7(20): 63-70

2. Abdulqader, A.A.; H.H.Suliman, . and N.A. Dawod.. 2021. Some wood properties of meliaa azedarach L. trees grown in Duhok province. Iraqi Journal of Agricultural Sciences, 52(3):774-782

3.Albeyboni, D. J. 2019. Evaluation of Some Heavy Metals in Soil and Three Genera of Trees with Their Diversity and Urban Streetscape Design in Duhok City, Kurdistan Region-Iraq. M.Sc Thesis. College of Agricultural Engineering Sciences. University of Duhok, pp.28-29

4. Al-Mukhtar, K.A., S.M. AL-Allaf, and A.A. AL-Attar. 1982. Microscopic preparations. Ministry of Higher Education and Scientific researches. Baghdad, Iraq

5. AL-Taay, M.S.A., A.H.A. Al-Assie, and R.O Rasheed. 2018. Impact of Bazian cement factory on air, water, soil, and some green plants in Sulaimani City-Iraq. Iraqi Journal of Agricultural Sciences, 49(3):354-366.

6. Azmat, R., S. Haider, H. Nasreen, F. Aziz, and M. Riaz. 2009. A viable alternative mechanism in adapting the plants to heavy metal environment. Pakistan Journal of Botany, 41:2729-38

7. Bhatti, G.H. and M.Z. Iqbal. 1988. Investigations into the effect of automobile exhausts on the phenology, periodicity and productivity of some roadside trees. Acta Sociotatis Botanicorum Poloniae. P 57.

8. Bozdogan, E. 2016. Heavy metal concentration in leaves of Melia Azedarach as A Bio-monitor of traffic-related air pollution. Oxidation Communications. 39 (1-II): 756764

9. Brooks, R.M., M.V. Bradly, and T.I. Anderson. 1950. Plant micro-technique manual. Davis: University of California.

10. Ekpemerechi, S.E., M.A. Lala, L.A. Jimoda, A.I. Odiwe, and S.A. Saheed. 2014. Effect of air pollution on the foliar morphology of some species in the family Euphorbiaceae in south-western Nigeria. Journal of Science and Technology, 34: 21-29 
11. El-Khatib, A.A., D.E. Radwan, and A.A. Alramah-Said. 2012. Morpho-anatomical characteristics of olive (Olea europaea L.). Journal of Environmental Studies, 9: 65-72

12. Giełwanowska, I., E. Szczuka, J. Bednara, and R. Gorecki. 2005. Anatomical features and ultrastructure of Deschampsiaantarctica (Poaceae) leaves from different growing habitats. Annals of Botany, 96:1109-1119

13. Jahan, S. and M.Z. Iqbal. 1992. Morphological and anatomical studies of leaves of different plants affected by motor vehicles exhaust. Journal of Islamic Academy of Sciences, 5:1, 21-23

14. Kumar, M. and N. Nandini. 2013. Identification and evaluation of air pollution tolerance index of selected avenue tree species of urban Bangalore, India. International Journal of Emerging Technologies in Computational and Applied Science, 4: 388390

15. Kushwaha, U. R. Shrivastava, and A. Mishra. 2018. Dust pollution effects on the leaves anatomy of Catharanthus roseus and Nerium oleander growing along the road side of Rewa City (m.p.) The International Journal of Engineering and Science, 7 (9): 01-07

16. Mitu, K.J., M.A. Islam, P. Biswas, S. Marzia, and M.A. Ali. 2019. Effects of different environmental pollutants on the anatomical features of roadside plants. Progressive Agriculture, 30 (4): 344-351

17. Nowak, D.J., D.E. Crane, and J.C. Stevens. 2006. Air pollution removal by urban trees and shrubs in the United States. Urban for Urban Gree. 4: 115

18. Othman, B.A. and E.S. Kakey. 2021. Pesticides bioaccumulation and their soil pollutant effect. Iraqi Journal of Agricultural Sciences, 52(1):36-47

19. Pamay, B. 1992. Plant Material I. Uycan Press, Istanbul, Turkey, pp. 63

20. Phua, D.H., W.J. Tsai, J. Ger, J.F. Deng, and C.C. Yang. 2008. Human Melia azedarach poisoning. Clin Toxicol (Phila), 46 (10):1067
21. Rai, P.K. 2016. Biodiversity of roadside plants and their response to air pollution in an Indo-Burma hotspot region: implications for urban ecosystem restoration. Journal of AsiaPacific Biodiversity, 9: 47-55

22. Rai, P.K. and R.M. Mishra. 2013. Effect of urban air pollution on epidermal traits of road side tree species, Pongamiapinnata (L.) Merr. Journal of Environmental Science, Toxicology and Food Technology, 2: 2319-402

23. Salgare, S.A. and V.B. Thorat. 1990. Effect of auto exhaust pollution at Andheri (West), Bombay on the micromorphology of some trees. Journal of Ecobiology, 2(4): 267272

24. Shahbas, S.E. 2010. Trees and Shrubs. A field guide to the trees and shrubs of Kurdistan Region of Iraq. Duhok University Press, pp 427

25. Shaukat, S.S., M. Mushtaq, and Z.S. Siddiqui. 1999. Effect of cadmium, chromium and lead on seed germination, early seedling growth and phenolic contents of Parkinosinia aculeata L. and Pennisetum americanum L. Schumann. Pakistan Journal of Biological Sciences, 2: 1307-1313

26. Shrivastava, R. and A. Mishra. 2018. Air pollution induced changes in foliar miromorphology of road side shrub species Thevetiaperuviana and Plumeriaalbain Rewa City, MP, India. International Research Journal, 7(3): 1-7

27. Sodnik, H., J.J. Skrezyna, and J. Staszkiewicz. 1987. The effect of industrial pollution in Walbrzych (Poland) on the size and shape of leaves of selected species of trees. Rocz Sekc Dendrol Pol Tow Bot, 36:1734

28. Tiwari, S. 2012. Air Pollution Induced changes in Foliar Morphology of two shrub species at Indore city, India. Research Journal of Recent Sciences, 2:195-199. 